\title{
Mechanism of effective orthotic therapy for the painful cavus foot
}

\author{
Bijan Najafi', James Wrobel ${ }^{2}$, Joshua Burns ${ }^{3^{*}}$ \\ From Australasian Podiatry Council Conference 2013 \\ Sydney, Australia. 2-5 June 2013
}

\section{Background}

People who have extremely high-arched feet or pes cavus often suffer from substantial foot pain. Custommade foot orthoses have been shown to be an effective treatment option, but their specificity is unclear. It is generally thought that one of the primary functions of custom foot orthoses is redistribution of abnormal plantar pressures. This study sought to identify variables associated with pain relief after custom foot orthoses intervention.

\section{Methods}

Demographic, physical characteristics and Pedar $^{\circledR}$ in-shoe plantar pressure data from a randomised controlled trial of 154 participants with painful pes cavus were retrospectively re-analysed at baseline and three month post orthoses intervention. The participants were randomised to a treatment group prescribed custommade foot orthoses or a control group given sham orthoses.

\section{Results}

No relationship between change in pressure magnitude and change in symptoms was found in either group. While redistribution of plantar pressure, measured with the Dynamic Plantar Loading Index, had a significant effect on pain relief $(p=0.03)$. Our final model predicted $73 \%$ of the variance in pain relief from custom foot orthoses and consisted of initial pain level, BMI, foot alignment, and changes in both Dynamic Plantar Loading Index and pressure-time integral. Results indicate that a primary function of effective orthotic therapy is redistribution of abnormal plantar pressures.

\footnotetext{
* Correspondence: joshua.burns@sydney.edu.au

${ }^{3}$ The University of Sydney and The Children's Hospital at Westmead, Sydney, Australia

Full list of author information is available at the end of the article
}

\section{Conclusion}

This study provides the mechanism by which custommade foot orthoses reduce pain and disability in patients with painful pes cavus. The proposed model may assist in better designing and assessing orthotic therapy for pain relief in patients with a variety of painful foot disorders.

\section{Author details}

${ }^{1}$ Interdisciplinary Consortium on Advanced Motion Performance (iCAMP), Southern Arizona Limb Salvage Alliance (SALSA)/Arizona Center on Aging, University of Arizona College of Medicine, Tucson, AZ, USA. Internal

Medicine; Metabolism, Endocrinology and Diabetes Division, University of Michigan Medical School, Ann Arbor, MI, USA. ${ }^{3}$ The University of Sydney and The Children's Hospital at Westmead, Sydney, Australia.

Published: 31 May 2013

\section{doi:10.1186/1757-1146-6-S1-O3}

Cite this article as: Najafi et al:: Mechanism of effective orthotic therapy for the painful cavus foot. Journal of Foot and Ankle Research 2013 6(Suppl 1):O3.

\section{Submit your next manuscript to BioMed Central and take full advantage of: \\ - Convenient online submission \\ - Thorough peer review \\ - No space constraints or color figure charges \\ - Immediate publication on acceptance \\ - Inclusion in PubMed, CAS, Scopus and Google Scholar \\ - Research which is freely available for redistribution

